\title{
Educating The Next Generation Of Business Students
}

\author{
B. Wailoo, Kean University, USA
}

S. John, Saint Peters University, USA

\begin{abstract}
Business students take courses in Financial Accounting where they learn the basic financial statements and how to present and analyze them. Accounting majors immediately experience a frustrating situation as they continue their studies with the Intermediate Accounting I course. Practicing accountants realize when they attend continuing education courses that understanding how to apply accounting concepts/theory is difficult. Other business majors may not experience the same frustration until they start their careers and find difficulty applying what they learned in Financial Accounting on the job. The authors argue that in all the above cases, including the use of acronyms in solving accounting problems is a critical teaching strategy for all business majors.
\end{abstract}

Keywords: Teaching Strategy; Acronyms; Professional Education; Transition from Principles to Intermediate Accounting Courses; Sustainability Strategy; Strategic Learning

\section{INTRODUCTION}

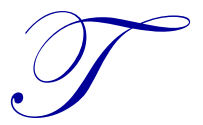

here is a number of challenges that educators face in preparing the next generation of business professionals as they prepare for their careers. The use of technology in the classroom was discussed in a prior paper (Schader, Wailoo, and John, 2012). In addition, there are curriculum content issues that business faculty are grappling with. The volume of material now available in each course makes for difficult choices in selecting specific material for inclusion in a course.

Accounting majors face a critical point in their studies when they have completed Principles of Accounting $1 \& 2$ and are sitting in Intermediate Accounting 1. Their Advisors have made it clear that the transition from Principles to Intermediate can be a difficult one. The financial statements and all the issues around those statements are covered in a much more rigorous way than in their Principles course. Some professors use a precipice analogy in describing the gap that students are facing between Principles and Intermediate courses. To navigate the gap and get to the next mountain range will require critical thinking skills and well developed problem-solving capabilities. Without these, the student may wind up in the valley with no discernible way out.

This paper focuses on using acronyms as a teaching strategy. Such a strategy will serve students well as they move toward ever more complex course material. Students will also find these skills useful in their business careers.

Every business specialty area has numerous acronyms that must be mastered. Introducing acronyms early on in their curriculum assures that students will be familiar with the use of acronyms, and their confidence will grow as their problem-solving capabilities develop.

\section{Using Acronyms As A Teaching Strategy}

Wikipedia defines mnemonics (Acronyms) as a learning technique to aid information retention. This technique is used to improve memory through learning and practicing. Mnemonics are often used for lists such as short poems, memorable phrases, and acronyms. Acronyms are formed from the first letters of each word in a series of words, such as Chief Executive Officer (CEO) or Sonar (SOund Navigation and Ranging). 
Acronyms have proliferated in every aspect of the accounting world - text books, financial accounting standards, tax laws, continued professional education, to mention just a few. This article lists about 300 acronyms in usage at the time of writing. Following are examples as to the extent in which they are used:

1. Principles of Financial Accounting - Examples

(a) Accounts Receivables are presented on the balance sheet at NRV; i.e., gross receivables minus allowance for doubtful accounts. TERM 2/10/n30, FOB shipping or FOB destination.

(b) The method of accounting for Inventories may be FIFO, LIFO, LCM, or average cost.

(c) Property and Equipment can be depreciated on the straight line or using an ACLRDM, such as the DDB method.

2. Accounting Theory and Intermediate \& Advanced Accounting

(a)

\section{A Brief History:}

In 1939, the Committee on Accounting Procedures and Terminology (CAPT) was established and began issuing Accounting Research Bulletins (ARB); the first step toward standardizing accounting policies and procedures. In 1959, CAPT was replaced by the Accounting Principles Board (APB). The APB gave way to the Financial Accounting Standards Board (FASB) in 1973. In the same year, the International Accounting Standards Committee (IASC) was created, which was then replaced by the International Accounting Standards Board (IASB) in 2001.

The FASB issued Financial Accounting Standards (FAS) and IASC issued International Accounting Standards (IAS). The IASB issues International Financial Reporting Standards (IFRS). On July 1, 2009, the FASB did a major restructuring of the United States accounting and reporting standards through the Accounting Standards Codification (ASC). New standards will now be Accounting Standards Updates (ASU). The Securities and Exchange Committee (SEC) recognizes both the FASB and the IASB and has agreed to accept financial statements prepared on IFRS without reconciling to GAAP. Other bodies of note and importance are Emerging Issues Task Force (EITF), International Financial Reporting Interpretations Committee (IFRIC), and the Standards Interpretations Committee (SIC). The Public Company Accounting Oversight Board (PCAOB), which came as a result of Sarbanes Oxley Act (SOX), is not involved.

(b) The FASB's ASCs will become the source of authoritative U. S. GAAP recognized by the FASB to be applied by non-governmental entities. Rules and Interpretive releases of the SEC under authority of federal securities laws are also sources of authoritative GAAP for SEC registrants.

The Board will no longer issue new standards in the form of statements, Financial Accounting Standards Board Staff Positions (FASBSP), or Emerging Issues Task Force Abstracts (EITFA).

3. Professional Education

Example: Fair Value Accounting (FVA)

The FASB, the AICPA, and the IASB set the accounting standards. The SEC and the PCAOB enforce the rules, along with the International Association of Security Commissions (IOSC). SFAS \#157 sets the accounting requirements for FVA. FASB codification topic \#820 clarifies Fair Value Measurement (FVM) concepts required by existing standards for financial reporting. A recently completed joint project of the IASB and the FASB developed a common FVM guidance to ensure that fair value has the same meaning in US GAAP and IFRS. Fair value is now commonly defined as the price that would be received to sell an asset or paid to transfer a liability in an orderly transaction between market participants at the measurement date. 
As you can see, accounting jargon is teeming with acronyms. Acronyms for Accountants are useful tools to assist accountants, educators, and students to understand accounting issues, standards, and requirements, as well as the language of the profession. The objective is to enhance reading and understanding writings by the Appraisal Issues Task Force, opinions by the Accounting Principles Board, the Accounting Standards Codification, the Accounting Standards Updates from the Financial Accounting Standards Board, and, of course, pronouncements from the new and exciting International Financial Reporting Standards. The list is used for quick reference without missing the key concepts of the topics, thus enhancing knowledge. We developed this list from our accounting experience in business and academia. We use them regularly in our accounting classes at every level. Students pick up the concepts quickly with this approach and it makes practical applications easier and more effective.

As stated in the introduction, the student has completed Principles $1 \& 2$ and is moving into Intermediate. The student knows to prepare financial statements and what the main elements of these statements are, such as assets, liabilities, equity, revenues, and expenses. It is now time to understand the Financial Accounting Concepts (FACs) and the Financial Accounting Standards (FASs) upon which accounting is built; i.e., the objectives of financial reporting, the qualitative characteristics of financial reporting, recognition and measurement assumptions, and other detailed elements of these statements. FASs follow the FACs by setting rules and guidelines of accounting for items within each element of the statements, e.g. accounting for contingencies, accounting for leases, etc.

Examples of usage of acronyms in Intermediate Accounting:

1. There are conceptual frameworks upon which both U.S. GAAP and IFRS are built. The frameworks are similar in most cases. The IASB and FASB have similar measurement principles on historical cost and FVM. U.S. GAAP issued SFAC \#7 as a guide to fair value. As stated above, the FASB and the IASB recently developed a common approach to FVM accounting.

2. FASB Statement \#162 states that the FASB Codification will become of authority for U.S. GAAP by the FASB for non-governmental entities effective September 15, 2009. Rules of the SEC are also sources of authoritative for SEC registrants. Again, the FASB will not issue new standards in the form of Statements, FASBSPs, or EITFAs. Instead, it will issue ASUs.

3. FASB ASU \#105 relates to Generally Accepted Accounting Principles (GAAP). This identifies changes resulting from the transition of FASBs to ASUs as it relates to GAAP. One section of ASU \#105 contains a list of XBRL elements for usage on the balance sheet, such as Cash, Cash Equivalents, and Short-term Investments, LIFO inventory, Accounts Payable, Bonds; i.e., every category of the balance sheet.

International and Advanced Accounting courses also utilize acronyms and students must become proficient in using acronyms as part of their theoretical and problem-solving skills. As was indicated before, the FASB and the IASB are working toward a convergence between GAAP and IFRS. A number of standards are already common to both. The international structure comprise of:

1. $\quad$ IFRS - issued after 2001

2. $\quad$ IAS - issued before 2001

3. IFRIC - issued after 2001

4. $\quad$ SIC - issued before 2001

5. Framework for the Preparation and Presentation of Financial Statements

The IFRS financial statements consist of the following (per IAS 1-8):

1. A Statement of Financial Position (SOFP)

2. A Comprehensive Income Statement (CIS)

3. Either a Statement of Equity (SOCE) or a Statement of Recognized Income or Expense (SORIE)

This is clear evidence how understanding acronym usage impacts every level of accounting. It is not just accounting education whether it's undergraduate or continuing professional education that is impacted by the use of acronyms. 
Many organizations are formulating sustainability strategies and the CFO is often asked to lead the implementation of these strategies. Following is an example of how acronyms, both financial and otherwise, impact all business disciplines:

Laurie, a recent marketing major graduate, started the job of her dreams. Her employer, a global consumer products company, hired her as an entry-level marketing analyst. She saw her career opportunities as open-ended based on her performance. The company was known to fast track employees who demonstrated high levels of contribution to important initiatives. Their sustainability strategy was just such an opportunity for Laurie. The CFO was appointed as the leader of this important new strategy and Laurie was assigned to the team as the Marketing departments representative. Her work with the team would be visible internally as well as to customers, stock analysts and investors.

At the team formation meeting, Laurie's head was spinning. All sorts of acronyms were being thrown out by the financial and other business specialties on the team. Laurie was leaving the meeting with a sinking feeling about her role and how her performance would be evaluated as the team did its work. All of a sudden her open-ended career opportunities were looking more like her being removed from the team. Laurie had taken financial accounting as part of her marketing curriculum. She remembered debits, credits, trial balance, and the financial statements, but never so many abbreviations. She was determined to succeed on this team, but, clearly, she would be doing a lot of homework over the next several months. A gnawing feeling came over her as she posed the question to herselfwhere do you start to get smart about financial acronyms?

One of the many challenges today in educating the next generation of business professionals is providing them with an integrated curriculum. Many curriculums are still separated into the functional areas of business with little opportunities for students to learn how all the functional areas of business connect to each other to produce an effectively operating business. Accounting faculty can utilize acronyms as an effective teaching strategy to connect the dots between the business disciplines in designing the Capstone course in the curriculum. Students, such as Laurie, would be exposed to the use of financial acronyms as they relate to the other disciplines. Sustainability strategies (John, 2012) require that all business disciplines, as well as IT, Legal, HR, etc., work together to effectively execute the strategy.

\section{CLOSING THOUGHTS}

The business world is increasingly becoming more complex and needs all current business people, as well as students, to develop more rigorous approaches to understanding problems they must solve and to apply their learnings to more effectively implement an organization's strategy (John, 2009). Introducing all students early in their career to acronyms will better prepare them to face these complexities. Introducing acronyms into introductory financial accounting courses will increase the ability of all business majors to apply accounting concepts and theories in their work assignments. Practicing accountants will also benefit if CPE courses are offered that use acronyms as a teaching strategy. All business majors will benefit from being introduced early in their undergraduate courses to financial and other business discipline acronyms. Business faculty should lead the way in revising and integrating acronyms into curriculum to ensure that graduates of their programs will add value to the companies they join as well as to the communities in which they work and live.

\section{AUTHOR INFORMATION}

Dr. Stephen John, EdD, MBA/CPA, is currently an Associate Professor in Business Administration at Saint Peters University. Prior to this he served as the Executive Director of the School of Accountancy/Finance for Kean University. Steve's current research is: 1) Educating the Next Generation of Business Leaders: Accounting for Sustainability (a new course created for undergraduates, graduate students and executive education), 2) Building Successful Change Alliances between the CFO, CHRO and local communities, and 3) Sustainable Identity as a Competitive Advantage. Prior to his joining Kean, Steve was a Senior Human Resource executive responsible for executive education/organizational effectiveness for sanofi aventis, Brown Brothers Harriman, Andersen, UBS, Marsh and Coopers \& Lybrand. Steve has a doctorate in Adult Learning and Leadership from Columbia University. He has an MBA/CPA. He has a BS in Physics with a specialty in using Cyclotrons. E-mail: sjohn@saintpeters.edu (Corresponding author) 
Professor Bert Wailoo, MBA, CPA, CMA, CFF, CGMA, is a Senior Professor in the Department of Accounting and Finance at Kean University. Prior to joining Kean, he worked in both the private and public sectors. He held Financial and Managerial positions at International Paper Company, Becton Dickinson, the Newark School of the Arts, and the Union Township Action Organization. Professor Wailoo's current research writing is on: 1) Financial Concepts and Financial Reporting Standards entitled - 168 Financial Accounting Standards Made Easy and 2) Business Valuation and the Role of Forensic Accountants in Divorce Settlements. He holds an MBA, CPA, CMA, CFF, and CGMA Certification. E-mail: Kean203@AOL.com (Corresponding author)

\section{REFERENCES}

1. Financial Accounting Standards Board (2012). Summary of Statement No. 168

2. Financial Accounting Standards Board (2012). ACU \#105 Generally Accepted Accounting Principles

3. John, S. (2009). "Strategic Learning and Leading Change: How Global Organizations are Reinventing $H R$ ". Elsevier Butterworth Heinemann. Oxford, UK.

4. John, S. (2012). "Implementing Sustainability Strategy: A Community Based Change Approach". International Journal of Business Insights and Transformation. Volume 4, Special Issue 3.

5. Kieso, Weygandt, Warfield (2010). "Intermediate Accounting” Volume 1, IFRS Edition, John Wiley\& Sons, Hoboken, NJ.

6. Schader, Wailoo, and John (2012). "Educating the Next Generation of Accounting Professionals" American Journal of Business Education. Volume 5, No 4.

7. Wikipedia

8. Zyla, Mark (2012). "Fair Value Measurements", John Wiley \& Sons, Hoboken, NJ. 


\section{APPENDIX}

\section{Partial List of Acronyms}

AAA - American Accounting Association

AAG - Auditing and Accounting Guides

AAML - American Academy of Matrimonial Lawyers

ABP - Annual Business Plan

$\mathrm{ABV}$ - Accredited in Business Valuation

ACLRDM - Accelerated Depreciation Methods

ACOs - Accountable Care Organizations

ACS -Automated Collection System

AcSEC - Accounting Standards Executive Committee

ADR - Alternative Dispute Resolution

AFR - Applicable Federal Rate

AFS - Available- For- Sale

AIA - American Institute of Accountants (Preceded the AICPA)

AICPA - American Institute of Certified Public Accountants

AIN - Accounting Interpretations

AITF - Appraisal Issues Task Force

ALA - Accountant's Liability Act

ALEC - American Legislative Exchange Council

AM - Accredited Member of the ASA

AMT - Alternative Minimum Tax

APB - Accounting Principles Board (1957- 1973)

APBs - Accounting Principles Board Opinions (1959-1973)

ARB - Accounting Research Bulletins (1939-1953)

ARM - Adjustable Mortgage

ARO - Asset Retirement Obligations

ARRA- American Recovery and Reinvestment Act

ASA - American Senior Appraiser

ASA - American Society of Appraisers

ASC - Accounting Standards Codification

ASR - Accounting Series Releases

ASU - Accounting Standards Updates

ATEOTD - At The End Of The Day

ATGs - Audit Techniques Guides

BCI - Brain Computer Interface

BDF - Beneficiary Designation Form

BEP - Break Even Point

BEV - Business Enterprise Value

BFF - Best Friends Forever

BLS - Bureau of Labor Statistics

BRICS - Brazil, Russia, India, China

BSA - Bank Secrecy Act

BVR - Basic Valuation Update

BYOD - Bring Your Own Device

CAATTS - Computer Assisted Auditing Tools \& Techniques

CAC - Contributory Asset Charges

CAF (IRS) - Centralized Authorization Form

$\mathrm{CAO}$ - Chief Accounting Officer

CAP - Collection Appeals Program

CAPM - Capital Asset Pricing Model

CAPT - Committee on Accounting Procedure and Terminology (1938-1959) 
CCFL - Center for Corporate Financial Leadership

CD- ROM - Compact Disc- Read Only Memory

CDP - Collection Due Process

CEO - Chief Executive Officer

CEPA - Conscientious Employee Protection Act

CES - Consumer Expenditure Survey

$\mathrm{CFF}-$ Certified in Financial Forensics

$\mathrm{CFO}$ - Chief Financial Officer

CITP - Chartered Information Technology Professional

CMEA - Certified Machinery and Equipment Appraisal

CNC - Currency Not Collectible

COBRA - Consolidated Omnibus Budget Reconciliation Act

COD - Cancellation of Debt

CODI - Cancellation of Debt Income

COI - Cancellation of Indebtedness

COJ - Confessions Of Judgment

CPE - Continued Professional Education

CRA - Community Reinvestment Act

CRAs - Consumer Reporting Agencies

CRS - Capital Rate Sensitivity

$\mathrm{CSO}$ - Content Specification Outline

CVP - Cost Volume Profit

DCF - Discounted Cash Flows

DDB - Double Declining Balance

DDIA - Direct Debit Installment Agreement

DIG - Derivatives Implementation Group

DIY - Do It Yourself

DOD - Date of Death

DOLR- Department of Labor Reviews

DR/BC - Disaster Recovery/Business Continuity Planning

DRS - Discount Rate Sensitivity

EAA - European Accounting Association

EBIT - Earnings Before Interest and Taxes

EBP - Employee Benefits Plans

EBPAQC- Employee Benefit Plans Audit Quality Center

EBSA- Employee Benefit Security Act

EDGAR - Education Department General Administrative Regulations

EDGAR - Electronic Data Gathering And Retrieval

EFTPS - Electronic Federal Tax Payment System

EIN - Employer Identification Number

EITF - Emerging Issues Task Force

EITFA - Emerging Issues Task Force Abstracts

EPM - Enterprise Performance Management

EPS - Earnings Per Share

ERI - Economic Research Institute

ERISA - Employee Retirement Income Security Act

ERM - Enterprise Risk Management

ERP - Equity Risk Premium

ESA - Egg Shell Audit

ESOP - Employee Stock Ownership Plan

ETIC - Earned Income Tax Credit

EZs - Enterprise Zones

FAC - Financial Accounting Concepts

FACTA - Fair and Accurate Credit Transaction Act 
FAF - Financial Accounting Foundation

FAQ - Frequently Asked Questions

FASAC - Financial Accounting Standards Advisory Council

FASB - Financial Accounting Standards Board (1973 - present)

FASBSP - Financial Accounting Standards Board Staff Positions

FATCA - Foreign Account Tax Compliance Act

FBAR - Foreign Bank Account Report

FCAG - Financial Crisis Advisory Group

FCRA - Fair Credit Reporting Act

FDIC - Federal Deposit Insurance Corporation

FHA - Federal Housing Administration

FIFO - First In First Out

FIN - Financial Interpretations

FLLC - Family Limited Liability Company

FLP - Family Limited Partnership

FMV - Fair Market Value

FOB destination - Free On Board destination

FOB shipping - Free On Board shipping point

FOIA - Freedom of Information Act

FRR - Financial Reporting Releases

FRS- Financial Reporting Standard (UK)

FSP - Financial Staff Positions

FTA - Fraud Technical Advisor

FTB - Financial Technical Bulletins

FTC - Federal Trade Commission

FVA - Fair Value Accounting

FVM - Fair Value Measurement

FVS - Forensic and Valuation Services

GAAP - Generally Accepted Accounting Principles

GAAS-Generally Accepted Accounting Standards

GAO - Government Accounting Office

GASAC - Government Accounting Standards Advisory Council

GRAT - Grantor Retained Annuity Trust

GST - Generation Skipping Tax (to grandchild)

GSTT - Generation Skipping Tax Transfer

HIDTA - High Intensity Drug Traffic Area

HIPAA - Healthcare Insurance Portability Accountability Act

$\mathrm{HOH}$ - Head Of Household

HTM - Held-to- Maturity

IAAER - International Association for Accounting Education and Research

IAS - International Accounting Standards

IASB - International Accounting Standards Board

IASC - International Accounting Standards Committee

ICS - Independent Contractor Services

IDR - Information Document Requests

IFAC - International Federation of Accountants

IFRIC - International Financial Reporting Interpretations Committee

IFRS - International Financial Reporting Standards

IGVBT - The International Glossary of Business Valuation Terms

ILIT - Irrevocable Life Insurance Trust

IMA - Institute of Management Accountants

IMHO - In My Humble Opinion

IMHO - In My Humble Opinion

IOSCO - International Association of Security Commissions 
IPO - Initial Public Offering

IPR\&D - In Process Research \& Development

IPR\&D - In Process Research \& Development

IPSU - Identity Protection Specialized Unit

IR - Interpretive Releases

IRA - Investment Retirement Act (Individual Retirement Account)

IRC - Internal Revenue Code

IRD - Income in Respect of a Decedent

IRJAF - International Research Journal of Applied Finance

IRM - Internal Revenue Manual

IRP - Industry Risk Premium

IRR - Internal Rate of Return

IRS - Internal Revenue Service

IRS CID (CI) - Internal Revenue Service Criminal Investigation

IRS's CI - The IRS Criminal Investigative Branch

ISAR - International Standards and Reporting

ITAC - Investors Technical Advisory Committee

ITF - Investor Task Force

IVSC - International Valuation Standards Council

JEEP - Joint Ethics Enforcement Program

LCM - Lowe of Cost or Market

LDC - Lead Development Centers (Relates to the IRS)

LEM - Law Enforcement Manual

LIBOR -London Inter-Bank Offering Rate

LIFO - Last In First Out

LIGF - Lender In Good Faith

LLC - Limited Liability Company

LMSB - Large and Mid-Sized Businesses

LUOI - Large, Unusual \& Other Items

MACRS - Modified Accelerated Cost Recovery System (Tax depreciation)

MD\&A - Management's Discussions and Analysis

MDRA - Mortgage Debt Relief Act

MLATs - Mutual Legal Assistance Treaties

MLTN - More Likely Than Not

MMI - Mind Computer Interface

MOU - Memorandum Of Understanding

MPEEM - Multiple-Period Excess Earnings Method

MSOL - Marital Standard Of Living

NAAATS - National Advanced Accounting \& Auditing Technical Symposium

NAC - Not-for-Profit Advisory Committee

NACS - National Association of Convenience Stores

NACVA - National Association of Certified Valuation Analysis

NAICS - North American Industrial Classification System

NASBA - National Association of State Board of Accountancy

NASDAQ - National Association Securities Dealers Automated Quotations

NAV - Net Asset Value

NFP - Not For Profit

NFTL - Notice of Federal Tax Lien

NMLS - National Money Laundering Strategy

NOL - Net Operating Loss

NRIs - Non-Resident Indians (From India)

NRV - Net Realizable Value

NYSE - New York Stock Exchange

OCBOA- Other Comprehensive Basis of Accounting 
OCDETF - Organized Crime Drug Enforcement Task Force

OCI - Other Comprehensive Income

OFL - Optional Format Letter

OIC - Offer In Compromise

OTA - Office of Taxpayer Advocate

OVDI - Off Shore Voluntary Disclosure Act

P/E ratio - Price Earnings Ratio

PAL - Passive Activity Loss

PAS - Professional Accounting Service

PB - Practice Bulletins

PB - Primary Beneficiary

PCAOB - Public Company Accounting Oversight Board

PCFRC - Private Company Financial Reporting Committee

PFI - Prospective Financial Information

PFS - Professional Financial Services

PIGS - Portugal, Ireland, Greece, Spain

PLR - Prime Lending Rate

POA - Power of Attorney

PPA - Pension Protection Act

PPIA - Partial Payment Installment Agreement

QDRO - Qualified Domestic Relations Order

QDT - Qualified Domestic Trust

QE 2 - Quantitative Easing - Feds Printing Money

QPRT - Qualified Personal Residence Trust

QSPEs - Qualifying Special Purpose Entities

QTIP - Qualified Terminal Interest Property

RAP - Regulatory Accounting Principles

RAR - Revenue Rolling

RBD - Required Beginning Date

REIT - Real Estate Investment Trust

REV - Reasonable Equivalent Value

RFR - Risk Free Premium

RIA Checkpoint - Rich Internet Application

RMD - Required Minimum Distribution

ROFL - Rolling On Floor Laughing

RTO - Recovery Time Objectives

S\&P 500 - Standard and Poors 500

SAB - Staff Accounting Bulletins

SAC - Standards Advisory Council

SAS - Statement of Auditing Standards

SB/SE - Small Business/Self Employed

SBAC - Small Business Advisory Committee

SBIA - Small Business Installment Agreements

SBR - Standard Business Reporting

SCRP - Specific Company Risk Premium

SEC - Securities and Exchange Committee

SFAC - Statement of Financial Accounting Concepts

SIC - Standard Industrial Classification

SIC - Standing Interpretations Committee

SIPC - Securities Investor Protection Corporation

SME - Small and Medium Enterprises

SOP - Standards of Position

SOX - Sarbanes Oxley Act (2002)

$\mathrm{SP}$ - Size Premium 
SPE - Special Purpose Entities

SS - Surviving Spouse

SSP - Strategy and Program Plan

SSVS1 - Statement of Standards for Valuation Services

STTP - Short Term Periodic Payment

SYG - Stand Your Ground

TARP- Troubled Assets Relief Fund

TAS - Taxpayer Advocate Service

TBTE - Tenancy By The Entirety

TDE - The Domino Effect

TDI - Temporary Disability Insurance

TEFRA - Tax Equity and Fiscal Responsibility Act

TEGE - Tax Exempt Government Entities

TERM $2 / 10 / \mathrm{n} 30-2 \%$ discount if paid within 10 days, net due in 30 days

TIAA-CREF - Teachers Insurance and Annuity Association-College Retirement Equity Fund

TIN - Tax ID Number

TIPRA - The Tax Increase Prevention and Reconciliation Act

TIS - AICPA Technical Information Service

TLA - Three Letter Acronym

TLA - Three Letter Acronym

TP - Tax Payer

TS - Trading Securities

TVA - Tennessee Valley Authority

UCC - Uniform Commercial Code

UFTA- Uniform Fraud Transfer Act

USC - United States Code (of laws)

USPAP - United Standards of Professional Appraisal Practice

VAT - Value Added Tax

VIE - Variable Interest Entity

VRG - Valuation Resource Group

W\&I - Wage and Investment

WAAC - Weighted Average Cost of Capital

WET - Weak Excuse Tendency

XBRL - Extensible Business Reporting Language 


\section{NOTES}

